factors. The depth and stability of motivation are determined by the correlation of value orientations, aspirations of the individual with the external conditions of the implementation of competence. It is noted that the new methodological foundations of postmodernism significantly influenced the innovative development of education. Instead of dogmatism, we have relativism: the principle of objectivity, unambiguity of determination, logic has changed to unlimited pluralism, essential relativism, subjectivism, irrationalism, etc. Based on the analysis of key factors determining the innovative development of education, the main results of work are formulated: firstly, clarification (in accordance with the context) of such concepts as innovations (in education), competence, competency and their interconnection; secondly, the scientific substantiation of the determining role of motivation in the formation of competence, the definition of the reasons for internal motives for mastering competence in external requests; thirdly, in defining methodological pluralism, correlation of objective laws and subjective factors in the imperatives of a competence model of education. The achieved results are aimed at practical realization in the field of pedagogical innovation.

Key words education, management, innovation, competence, competency, motivation, methodological pluralism.

удк 378.1

Ольга Цибулько

Маріупольський державний університет ORCID ID 0000-0003-1297-5465

DOI 10.24139/2312-5993/2020.01/127-137

\title{
ОСОБЛИВОСТІ ПЕДАГОГІКИ ДУХОВНОСТІ У СВІТЛІ СУЧАСНОГО СВІТСЬКОГО ТА РЕЛІГІЙНОГО ВИХОВАННЯ
}

у статті окреслено відмінності між світським $i$ релігійним, а саме християнським, підходом до виховання духовності. обидві педагогічні моделі орієнтуються в справі виховання на найвищі стандарти духовного виховання. Однак, розуміння самої духовності в секулярній та релігійній педагогіці різняться.

Установлено, що духовне виховання й духовний досвід православної педагогіки сприймається у світській педагогіці, звичайно, як високий ідеал, проте, лише тією мірою, в якій розуміння християнської духовності відповідає власному розумінню духовності взагалі.

Розкрито специфріку православної педагогіки, яка, визнаючи необхідність всебічного розвитку людини, постулює швидше ієрархічне виховання учнів, під яким розуміється така «модель людини», яка має на увазі, що на першому місці з необхідністю повинні стояти духовні цінності (що розуміються, природно, в релігійному сенсі), потім тільки душевні й матеріально-фрізичні.

Ключові слова: світська педагогіка, релігійне виховання, духовна педагогіка, духовність, духовні чінності.

Постановка проблеми. Перш ніж окреслити відмінності між світським і релігійним, а саме християнським, підходом до виховання духовності, слід зазначити очевидну подібність, яка полягає в тому, що обидві педагогічні моделі орієнтуються в справі виховання на найвищі стандарти духовного виховання. Однак розуміння самої духовності в секулярній та релігійній педагогіці різняться. 
у межах понять секулярної педагогіки «духовність» розуміється насамперед як морально-етичні якості людини, а також як орієнтація людини на служіння власній самореалізації. Ця тенденція проявляється не тільки в педагогіці та психології, але й у культурно-історичній сфері освіти. Духовне виховання й духовний досвід православної педагогіки сприймається у світській педагогіці, звичайно, як високий ідеал, проте, лише тією мірою, в якій розуміння християнської духовності відповідає власному розумінню духовності взагалі. Для практичної діяльності такий підхід може вважатися виправданим, коли для підтвердження необхідності виховання високогуманістичної особистості відбувається посилання на авторитетну релігійну традицію з глибоко гуманістичними цінностями, заснованими на любові людині до свого ближнього. Але разом із тим, суттєвою тенденцією в педагогіці $\epsilon$ імпліцитне сприйняття духовності як універсального явища, властивого всім, незалежно від народностей і релігійних систем. Виходячи з даних релігієзнавства, антропології, психології та філософії з цим погодитися важко. Така точка зору виникає якраз, виходячи з розуміння духовності як високого рівня морально-етичних якостей, які, згідно із загальнолюдськими принципами, повинні бути однакові для всіх.

Аналіз актуальних досліджень. У сучасній Україні значна кількість педагогічних досліджень присвячена дослідженню проблем, пов'язаних із суспільною кризою духовності й духовними викликами сьогоденної освіти. Значущим викликом морального виховання особистості $\epsilon$ розвиток духовності особистості як найціннішого явища у світлі сучасної педагогіки. До сфери зацікавленості вчених усе частіше потрапляє феномен світської та православної педагогіки духовності, адже високий рівень духовної культури особистості формує їі здатність до вільного вибору власного шляху, власного способу життя, заснованих на загальнолюдських морально-духовних цінностях.

У межах традиційної православної педагогічної думки тотожним поняттям «духовності» $€$ поняття «релігійність», а, отже, вчені розуміють поняття «духовність» як зв'язок особистості з Богом, поняття духовного виховання ототожнюються з релігійним вихованням. Разом із тим, спадщиною світської педагогіки стає особистість як найвища цінність у світі, як центр світобудови.

Проблеми духовності у вихованні особистості досліджували Д. О. Богданова, І. Д. Бех, А. М. Богуш, Т. В. Борисова, М.В.Даниленко, А. В. Зуєв, Л. С. Кальницька, Н. Лавриченко, Л. В. Нечаєва, Г. П. Шевченко. Разом із тим, окремого дослідження, присвяченого аналізу духовної педагогіки у світлі сучасного світського та релігійного виховання, немає.

Метою статті $€$ визначити особливості педагогіки духовності у світлі сучасного світського та релігійного виховання. 
Методи дослідження. У статті використані такі методи дослідження, як: власне теоретичні - аналіз філософської, педагогічної та психологічної літератури, задля доведення основних положень дослідження та інтерпретаційно-аналітичний метод, на основі якого досліджується наявна література із застосуванням синтезу, аналізу, систематизації та узагальнення.

Виклад основного матеріалу. Сучасна система освіти передбачає певні цілі, які стосуються всебічного гармонійного виховання особистості, проте з точки зору православної педагогіки духовності вищезазначена мета не відповідає духовним законам розвитку людини. Православна педагогіка, визнаючи необхідність всебічного розвитку людини, постулює швидше ієрархічне виховання учнів, під яким розуміється така «модель людини», яка має на увазі, що на першому місці з необхідністю повинні стояти духовні цінності (що розуміються, природно, в релігійному сенсі), потім тільки душевні і матеріально-фізичні. Так, ми бачимо, що розуміння людини в православній педагогічній антропології тонше, ніж у світській педагогічній антропології - крім фізичної та духовної складової, виділяється ще й душевна складова.

Основною рисою світської педагогіки $\epsilon$ те, що в якості основи й відправної точки виховання духовності в особистості, вона пропонує, в першу чергу, знання й мораль у перспективі очевидного успішного й морального функціонування людини в навколишньому фізичному світі. Православна ж педагогіка будується на визнанні абсолютної значущості категорій Добра та Зла, з визнанням існування реальності духовного світу (Борисова, 2009, с. 18). За такого підходу основним принципом стає не доброчесне життя й побудова справедливого суспільства, а орієнтація на божественну реальність, на особистого Бога - це, власне, те, що називається духовністю, тоді як самореалізація людини й допомога близьким лише випливає з першого принципу.

Іншими словами, християнська педагогіка в погляді на людину має на увазі наявність сфери моральності, включаючи сюди прагнення до самореалізації, але вважає це областю душевного, і в той самий час виділяє в людині духовну сферу, яка розуміється тісно пов'язаною зі сферою божественного, і реальність якої позначається абсолютною та не підлягає сумніву.

У світській системі моралі категорії добра та зла носять певною мірою відносний і лабільний характер, який пояснюється обґрунтуванням появи морально-етичних цінностей через культурно-історичні причини. У той час як у релігійній системі взагалі й у православному християнстві зокрема, морально-етичні цінності знаходять свою основу посиланнями на Бога й божественний закон, який, у свою чергу, $€$ незмінним незалежно від особливостей культурно-історичних трендів (Зуєва, 2007, с. 32). Вирішення питань духовного виховання, розуміння світу й навколишніх явищ, з цієї точки зору, $є$ першочерговими завданнями православної педагогіки. 
Оцінюючи ідеологічний базис світської педагогічної моделі з точки зору православного педагогічного досвіду, можна стверджувати, що для секуляризованої системи освіти духовне виховання стає бездуховним, тобто в ньому більше переважає матеріальна, фізична, психологічноморальна сторона, у той час як релігійна освіта оперує розумінням духовного в його власному філософсько-теологічному значенні.

Питання щодо дослідження єдиної педагогічної моделі навчання залишається актуальним і на сьогодні, адже це пов'язано зі стрімким розвитком науки, що вивчає створений Богом світ. Наука стала розвиватись окремо, незалежно від богослов'я, що вивчає шляхи пізнання Бога. 3 тих пір світська наука обмежилася питанням «як влаштований світ?». У той час як церква та їі інститути дають відповідь на питання «навіщо цей світ влаштований?» і «яке в ньому місце і роль людини?». Ті та інші пізнають закони Божі, але одні - фізичні, хімічні, біологічні, соціальні, а церква - духовні й моральні закони (Нечаєва, 2000, с. 11).

У сучасній системі освіти відображається й економічна криза, яка стала наслідком нестримного прагнення багатьох людей до матеріального збагачення на шкоду духовним основам життя. У навчальних програмах помітний винятковий прагматизм, орієнтація на успіх, гроші, славу. У ході наукових досліджень учені помітили тенденцію до збільшення закладах вищої освіти кількості студентів зі зниженим рівнем загальної, моральної та поведінкової культури. Однією з провідних причин цієї проблеми є зміна життєвих уподобань молоді. Задля вирішення цього питання деякі школи й університети впроваджують певні заходи з метою підвищення духовності в процесі навчання, адже вважається, що саме ліквідація духовної безграмотності буде сприяти набуттю сенсу життя молодими людьми, вирішенню їх внутрішніх протиріч, що призведе до лікування соціальних недуг. Науковці наголошують на тому, що сьогодні дуже важливо зберігати той духовний стрижень, який завжди був присутній в освіті.

Незважаючи на важливість вищезазначеного питання, процеси модернізації та глобалізації можуть призводити до відчуження індивіда від традиційних історико-культурних цінностей. Орієнтація на рівень споживання розвинених країн і культурна привабливість західного способу життя призводять до кризи власної ідентичності й неприйняття дійсності. 3 іншого боку, високий ступінь соціальної нерівності й відсутність загальновизнаних громадських ідеалів часто позбавляють підлітка позитивних світоглядних орієнтирів. Дані протиріччя вкрай негативно впливають на морально-етичне виховання школярів і студентів, сприяють формуванню деструктивної поведінки, i серйозно ускладнюють педагогічну роботу колективів шкіл та університетів (Бех, 2003). Культ «красивого життя» й розкоші, який нав'язується масовою культурою в 
суспільстві, веде до серйозної деформації світогляду, до ціннісного розколу між поколіннями, між учнями й педагогами.

Станом на сьогодні, сучасна педагогіка поки не має надійних методів виховного впливу, які здатні сприяти розвитку духовних якостей. Наприклад, усе частіше зустрічаються ситуації, коли школярі починають використовувати знання правових норм, насамперед, для чинення тиску на вчителів і знущання над ними. Вони можуть дозволити собі будь-яку хуліганську витівку, але при цьому вимагають поваги до себе й дотримання своїх прав. Про такий важливий чинник виховання, як авторитет учителя, в даній ситуації можна взагалі забути. Також слід зауважити, що останні десятиліття зросла кількість криміналізації в підлітковому віці. Усі ці фактори вкрай негативно впливають на духовно-моральне виховання школярів і вимагають системи комплексних заходів із реформування системи освіти, які, на жаль, тільки знаходяться на стадії розвитку.

Незважаючи на відсутність чіткого алгоритму щодо вирішення питання духовності в навчанні, загальне визначення сутності духовності залежить від прийнятого за основу джерела духовності, який різниться у видах конфесійної парадигми. Наприклад, атеїзм пропонує приймати в якості такого джерела силу матерії, але не може визначити критерії оцінки духу. Пантеїстичне розуміння духу зводиться до розгляду його як самостійної безособистісної суті, з якої формуються два божества, одне з них творить духовні сутності, а друге - матеріальний світ. Кожному з них приписуються діаметрально протилежні якості, і оскільки вони сутність породження єдиного початку, то тут, як і в атеїзмі, представляється неможливим виділення абсолютних критеріїв добра та зла. Однозначне розуміння критеріїв добра та зла можливо тільки в монотеїстичної парадигмі, де єдиним справжнім духом визнаний Бог, і тому все, що співвідноситься з Богом, розцінюється як благо (Даниленко, 2007, с. 26). Рішення проблеми духовності в педагогічних цілях зводиться до захисту учнів від деструктивних впливів у духовній сфері (наприклад, сектантства) і до створення умов для вироблення духовного імунітету за допомогою залучення до національної та світової класичних культур.

Питання духовності $€$ об'єктом дослідження багатьох учених, тому згідно з емпіричними даними наукових праць, «духовність» розуміється студентами як «віра в Бога» $(27,12 \%)$, «моральність» $(20,85 \%)$, «душа» $(17,48 \%)$, «взаємини» $(16,19 \%)$, також вельми високий відсоток опитаних пов'язує духовність із вірою в Бога. 3 точки зору більшості студентів $(97,26 \%)$, духовність має місце в житті людини, тому вона і є людиною, а не «роботом» або «твариною», здатною розвиватися й самовдосконалюватися (Кальницька, 2004, с. 85). Таким чином, без малого $100 \%$ сучасного студентства знайомі 3 терміном «духовність», що говорить про міцне укорінення даного терміну в масовій суспільній 
свідомості. В розумінні деяких студентів у духовності переважають їі екзистенційна й комунікативна складові, що свідчить про «приземлене», «поверхневе» сприйняття сфери духовності (релігійний компонент духовності виражений максимум у 5,2 \%).

3 приводу цього питання науковець К. Юнг зазначив у ході свого дослідження про те, що сучасна людина не розуміє, наскільки раціоналізм віддав ії під владу психічного «пекла». Філософ вважає, що людина звільнилася від «забобонів», розгубивши при цьому свої духовні цінності. Через це моральні й духовні традиції виявилися перервані, розплатою за це стали загальні дезорієнтація та розпад, що представляють реальну загрозу миру. Це дозволяє більш конкретно говорити про найважливіші поняття: Дух, Людський дух і Духовність, які слід розкривати, згідно $з$ Юнгом, не боячись «забобонів» і прагнучи відновити «здатність до сприйняття символів та ідей божественного» (Zohar, 2001). Проте вищезазначені поняття, що виступають у якості фундаментальних категорій, не можуть бути визначені в повному сенсі цього слова - їх можна характеризувати тільки в контексті, як результат розкриття цілісного вчення. Розглянемо більш детально кожен із них.

Першим, як правило, виступає поняття «Дух», який розуміється як об'єкт, який не може бути зафіксований природно-науковими методами. Це визначення потребує позитивного доповнення, тому в більшості своєму науковці висувають на передній план не сутність позначуваного предмета, а його зовнішні прояви.

Другим компонентом вважається все, що має Духовне ядро, наприклад дар вибору, переваги й самовизначення. Науковці конкретизують одного з носіїв духу - людину. Дух людини сприймається в науковому світі як особиста енергія, і до того ж розумна енергія; розумна не в сенсі «свідомості» або «розумового мислення», а в сенсі предметного споглядання, «зрячого» вибору й дії в силу духовно-достатніх підстав.

Третім елементом вважається Духовність, як форма людської самосвідомості, самоідентифікації, основа конституювання людини в ролі суб'єкта відносин, сфера сутності людини. Загальним як для релігійної, так і для світської свідомості є розуміння духовності, яке зв'язується з виходом за межі егоїстичних інтересів, особистої користі, корисливості. Духовне передбачає, що цілі й життєві орієнтири особистості вкорінені в системі надіндивідуальних цінностей.

Як ми бачимо, проблема духовності досить актуальна, особливо в останній третині минулого століття, коли тема духовності стала підніматися серед філософів, які шукають примирення з новими віяннями суспільної свідомості. В основному філософи-атеїсти прагнули визначити духовність, не зв'язуючи ії з традиційною релігійністю, з будь-якої метафізикою, тобто намагаючись залишатися виключно на матеріалістичних позиціях. 
3 точки зору атеїстичної філософії та соціології явище духовності розглядається досить неоднозначно. Оскільки дух розуміється як абстрактне, нематеріальне явище, то під духовністю розуміється спрямованість до високої моралі, етики й естетики, інтерес до всього піднесеного та прекрасного, особливо в поезії, музиці, літературі та інших видах мистецтва. Чим вище духовність людини, тим більшою мірою вона повинна володіти позитивними, кращими властивостями, бути прикладом для наслідування.

Згідно з культурологічним поняттям, духовна культура, або духовність, складається з багатьох галузей. Крім релігії, сюди входять усі галузі наук про природу й суспільство, література й поезія, всі види мистецтв - живопис, музичне мистецтво, скульптура, кіно, сценічне мистецтво, а також право, мораль, правила, зразки й норми поведінки, традиції, мову, церемонії, символи, звичаї, обряди, етикет тощо. Проте окремі представники церкви досить часто спотворюють поняття духовності та зводять їі тільки до релігійності.

Відображаючи позитивний зміст у секулярному підході до духовності, дослідники наголошують на тому, що для загального розуміння духовності значимі формулювання, що зв'язують її з ціннісним виміром свідомості. Автори наукових праць чітко виділяють і те, що відсутнє в секулярному визначенні духовності, але $\epsilon$ істотним компонентом практично в усіх релігіях, - наявність особливого духовного світу, розділеного на два полюси. У релігії духовність розуміється на тій самій основі, але зі сполученням її з духовним світом у цілому, який тут не вичерпується тільки людиною як істотою духовною, що володіє духовністю. Крім того, в релігії духовність - різноякісність, найчастіше полярна (світла й темна, божественна й диявольська).

Цілком певну релігійну позицію у визначенні духовності та проєкції цієї категорії на педагогіку висловлював Ш. Амонашвілі, який писав, що духовний аспект гуманної педагогіки становлять фундаментальні допущення. Вони є умовою розширення педагогічного свідомості. Такими допущеннями є: ідея творця, ідея безсмертя духу й ідея спрямованості до вічного вдосконалення та сходження.

Описання категорій, що належать до духовної сфери буття людства, має досить поширений підхід на основі історичного аналізу термінології досліджуваної галузі. Але в історичному аналізі сам термін починає розпливатися, він втрачає свої логічні контури, потопає в різних історичних фактах, отримує різне тлумачення й застосування в різні історичні епохи. Проте якщо визнати такий історико-феноменологічний аналіз духовності недостатнім, то як спосіб подолання цієї недостатності необхідно доповнити його дослідженням логіки розвитку вихідних понять, починаючи від простих, елементарних, іманентних аналізованому предмету (Лавриченко, 2003). 
Оскільки базовим елементом релігії $\epsilon$ «релігійне підґрунтя», що визначає тип духовності, ії першооснову, з якого випливає релігійне вірування, як культово-обрядовий компонент релігії, отже, релігійна система на релігійно-філософському рівні осмислює й розкриває зміст релігії. Оскільки вищі сили релігії можуть бути лише трьох типів: сили самої матерії в атеїзмі; сили божества, який породив із себе світ шляхом еманації в пантеїзмі; в монотеїзмі найвища сила - це Бог, що створив світ; то і духовність може бути зрозуміла як духовність атеїзму, пантеїзму або монотеїзму.

Представники християнської церкви, як і представники інших конфесій, говорять про зв'язок духовності й релігійності, і це цілком відповідає визначенню релігії, яка вказує першоджерело духовності, фіксує носіїв духовності та їх взаємини в духовній сфері буття. Крім того, саме релігія задає можливість виникнення полярності в духовному просторі. І якщо природничі науки не так очевидно просякнуті конкретним релігійним духом, то гуманітарні науки, мистецтво всіх видів, а також право, мораль, правила, зразки й норми поведінки, традиції, мова, церемонії, символи, звичаї, обряди, етикет тощо, чітко несуть в собі релігійний дух відповідної релігії.

Науковці, які підтримують секулярну точку зору з приводу даного питання розуміють дух, душу, духовність як усього лише метафізичні аналоги точних понять: свідомість, розум, моральність, психіка тощо, адже вони зручні для додання ідеальним діяльним силам, здібностям і прагненням людини відтінку особливої височини. Часто Дух визнають головним терміном духовності та релігії, тому відносно цього поняття підійти до конкретизації представляється можливим тільки після того, як буде виявлено джерело духу й дана характеристика джерела. Тільки після цього можна говорити про те, де і якою мірою має місце наповненість духом, тобто духовність, яка до того ж тісно пов' язана з культурним життям (Шевченко, 2004).

Культура ж сама по собі має неоднозначний вплив на людину, на що вказують дослідження сучасних учених, які пояснюють, що приписування культурі, ідеальній формі, середовищу, функцій рушійної сили розвитку змушує культуру, всупереч їі змісту, бути агресивною та залишає неясною роль її в процесі розвитку самого індивіда, який зрештою, сам стає джерелом і рушійною силою розвитку культури, цивілізації, стає змістом породження нових ідеальних форм, переосмисленням старих.

Проте, слід зазначити, що відносини людини й культури визнаються взаємно активними, комунікативними, діалогічними, адже стосунки можуть бути дружніми, напруженими, конфліктними й навіть переходити в агресію. Таке бачення цього питання стає ясним, якщо побачити, що культура формується сприйнятим культом, який цілком може виявитися культом «злого» язичницького божества, або культом Сатани, або демонізацією тощо (Богуш, 2000, с. 22). Саме з цієї причини відносини «людина-культура» вимагають критеріїв для самої культури, тобто 
зовнішніх по відношенню до культури, що, очевидно, і призводить до необхідності розглядати релігію як джерело духовності, що визначає культурні домінанти життя народу. Тому в процесі виявлення сутності духовності слід рухатися від абстрактного визначення духовності як єдності душі з об'єктивно-загальним духом, до конкретних її визначень, що відображає характер духовного досвіду суб'єкта та його ставлення до духовної реальності - онтологізацію, психологізацію, імперсоналізацію або, навпаки, персоналізацію духовної реальності (Bohdanova, 2017).

Якщо розглядати питання духовності суто з педагогічної точки зору, в галузі виховання етичних уявлень, основною проблемою атеїстичного розуміння духовності $\epsilon$ нездатність до формування критеріїв оцінки духу, відповідно й духовності. Історично такими оцінками виступали прогрес: науковотехнічний або громадський, класова свідомість, зростання матеріального добробуту. Дуже часто в якості критерію виступали особисті світоглядні уявлення певних авторів. Критерії, позначені історичним досвідом, досить відносні, ненадійні й, більше того, можуть бути досить небезпечні для особистості, суспільства й держави, адже з їх допомогою може бути сформований і виправданий режим тоталітаризму, беззаконня та свавілля, що наочно демонструє досвід усіх революцій, історія нацизму й фашизму.

Частіше за все ці проблеми духовності пов'язані із забезпеченням духовної безпеки, зокрема, в педагогіці. Наприклад, проблема сектантства, а точніше сектантської свідомості зараз $є$ дуже актуальною й викликає інтерес як у педагогів, так і у психологів. Нестійкість щодо традиційних ідеалів і цінностей, незнання історії та культури свого народу, а також ідеології, що породжує почуття егоцентризму та власної винятковості, формують бажання молодої людини до пошуку організації, де, поряд із дифірамбами на їі адресу, будуть запропоновані замінники всього іншого: псевдокультура, помилкові ідеали й цінності тощо.

Висновки та перспективи подальших наукових розвідок. Таким чином, задля рішення проблеми духовності, зокрема в системі освіти, розглядаються два шляхи: по-перше, необхідно захистити учнів від деструктивних впливів у духовній сфері, а по-друге, створити умови для вироблення у свідомості духовного імунітету, що значною мірою досягається за допомогою залучення до традиційної культури свого народу та світової класичної культури.

\section{ЛITEPATУРA}

Bohdanova, D. O. (2017). Spiritual and intellectual essence of pedagogical activity. Problems of Modern Psychology: Collection of research papers of Kamianets-Podilskyi Ivan Ohienko National University, G. S. Kostiuk Institute of Psychology at the National Academy of Pedagogical Science of Ukraine, 38, 53-67.

Zohar, D. (2001). Spiritual Intelligence: The Ultimate Intelligence.

Бех, І. Д. (2003). Виховання особистості. К.: Либідь (Beh, І. І. (2003). Personal education. K.: Libid). 
Богуш, А. М. (2000). Дефініції «духовність» і «моральність» в аспекті національного виховання в Україні. Морально-духовний розвиток особистості в сучасних умовах, 18-23 (Bogush, A. M. (2000). Definition of «spirituality» and «morality» in the aspect of national whirling in Ukraine. Moral and spiritual development of special features in ordinary minds, 18-23.)

Борисова, Т. В. (2009). Онтологія духовності крізь призму православної антропології. Інтелект. Особистість. Цивілізація, 7, 17-19 (Borisova, Т. V. (2009). Ontology of spirituality through the prism of Orthodox anthropology. Intellect. Specialty. Civilization, 7, 17-19).

Даниленко, М.В.(2007). Іманентні особливості духовно-етичного виховання майбутніх вчителів. Проблеми сучасної педагогічної освіти: Педагогіка і психологія, 13-29 (Danilenko, M. V. (2007). Immanent features of the spiritual and ethical whirlwind maybutnite readers. Problems of presently pedagogical education: Pedagogy and psychology, 13-29).

Зуєв, А. В. (2007). Ілюзія духовності в світі інформаційної завершеності. Актуальні проблеми духовності, 29-38 (ZuEV, A. V. (2007). Spiritual spirituality in the completion of information. Actual problems of spirituality, 29-38).

Кальницька, Л. С. (2004). Духовність як важлива категорія перехідної доби. Проблеми гуманізації навчання та виховання у вищому закладі освіти: матеріали других Ірпінських міжнародних науково-педагогічних читань, 83-88 (Kalnitska, L. S. (2004). Spirituality is important category of cross-product. Problems of humanization and whirlwind at the other mortgage mortgage: materials of other international educational and scientific readings, 83-88).

Лавриченко, Н. (2003). Категорії «соціальність», «духовність» і «моральність» в сучасній педагогічній науці. Шлях освіти, 1, 7-11 (Lavrichenko, N. (2003). The categories of «social», «spirituality» and «morality» are in the current pedagogical nature. Way of life, 1, 7-11).

Нечаєва, Л. В. (2000). Духовно-релігійна культура - основа морального виховання учнів. Наука і освіma, 5, 5-16 (NechaєVa, L.V. (2000). Spiritual Religion Culture - The Basis of Moral Vision. Science and education, 5, 5-16).

Шевченко, Г. П. (2004). Педагогіка духовності. Духовність особистості: методологія, теорія і практика, 1, 3-9 (Shevchenko, G. P. (2004). The pedagogy of spirituality. Spirituality of special features: methodology, theory and practice, 1, 3-9).

\section{PEЗЮМЕ}

Цыбулько Ольга. Особенности духовной педагогики в свете современного светского и религиозного воспитания.

В статье обозначены различия между светским и религиозным, а именно христианским, подходом к воспитанию духовности. Обе педагогические модели ориентируются в деле воспитания на самые высокие стандарты духовного воспитания. Однако понимание самой духовности в секулярной и религиозной педагогике различаются.

Установлено, что духовное воспитание и духовный опыт православной педагогики воспринимается в светской педагогике, конечно, как высокий идеал, однако, лишь в той мере, в которой понимание христианской духовности соответствует пониманию духовности вообще.

Раскрыта специфика православной педагогики, которая, признавая необходимость всестороннего развития человека, постулирует скорее иерархическое воспитания учащихся, под которым понимается такая «модель 
человека», которая подразумевает, что на первом месте с необходимостью должны стоять духовные ценности (понимаемых, естественно, в религиозном смысле), затем только душевные, и материально-физические.

Ключевые слова: светская педагогика, религиозное воспитание, духовная педагогика, духовность, духовные ценности.

\section{SUMMARY}

Tsybulko Olga. Peculiarities of spiritual pedagogy in the light of modern secular and religious education.

The article outlines the differences between the secular and the religious, namely the Christian, approach to the education of spirituality. Both pedagogical models focus on the upbringing of the highest standards of spiritual upbringing. However, the understanding of spirituality in secular and religious pedagogy differs.

It is established that the spiritual education and spiritual experience of Orthodox pedagogy is perceived in secular pedagogy, of course, as a high ideal, however, only to the extent that understanding of Christian spirituality corresponds to one's own understanding of spirituality in general.

The specificity of Orthodox pedagogy is revealed, which, recognizing the need for comprehensive human development, posits rather a hierarchical upbringing of students, which is understood as such a "human model", which implies that spiritual values should be placed in the first place (understood, of course, in religious sense), then only the spiritual and material-physical.

If we consider the issue of spirituality purely from a pedagogical point of view, in the field of education of ethical ideas, the main problem of atheistic understanding of spirituality is inability to form criteria for the assessment of spirit, respectively, and spirituality. Historically, such progress has been made: scientific and technological or public, class consciousness, and the growth of material well-being. Very often, the criterion was the personal outlook of certain authors. Criteria marked by historical experience are relatively relative, unreliable and, moreover, may be dangerous enough for the individual, society, and the state, because they can form and justify a regime of totalitarianism, lawlessness, and arbitrariness, demonstrating the experience of all revolutions, history of nazism and fascism.

Thus, in order to solve the problem of spirituality, in particular in the education system, two ways are considered: first, it is necessary to protect students from destructive influences in the spiritual sphere, and secondly, to create conditions for the development in the consciousness of spiritual immunity, which is largely achieved through involvement in the traditional culture of its people and the world classical culture.

Key words secular pedagogy, religious education, spiritual pedagogy, spirituality, spiritual values. 